\title{
Nicolau Syndrome Due to Diclofenac Injection: Case Report
}

\author{
Diklofenak Enjeksiyonuna Bağli \\ Nicolau Sendromu
}

\author{
Hakan TURAN, ${ }^{a}$ \\ Ayşegül TURAN ${ }^{b}$ \\ aDepartment of Dermatology, \\ Düzce University Faculty of Medicine, \\ Düzce \\ ${ }^{\mathrm{b}}$ Clinic of Dermatology, \\ Bitlis State Hospital, Bitlis \\ Geliş Tarihi/Received: 23.12 .2010 \\ Kabul Tarihi/Accepted: 24.05.2011 \\ Yazışma Adresi/Correspondence: \\ Hakan TURAN \\ Düzce University Faculty of Medicine, \\ Department of Dermatology, Düzce \\ TÜRKIYE/TURKEY \\ drhakanturan@gmail.com
}

\begin{abstract}
Nicolau syndrome is a rare and local complication of aberrant intramuscular injections of various drugs. It is characterized by a necrotic or hemorrhagic plaque, which follows a pale then consequently an erythematous macule on the injection area. It usually heals by leaving an atrophic scar. The exact pathogenesis is unknown. Nonetheless, a possible cause is the development of arterial spasm following tissue necrosis after the drug is injected into a blood vessel by mistake. Here, we presented a case of Nicolau syndrome occurring after the injection of diclofenac to the thigh region.
\end{abstract}

Key Words: Diclofenac; injections, intramuscular

ÖZET Nicolau sendromu, çeşitli ilaçların hatalı intramusküler enjeksiyonundan kaynaklanan nadir görülen lokal bir komplikasyondur. Enjeksiyon alanında önce soluk sonra belirgin eritemli makülü takip eden nekrotik veya hemorajik plak ile karakterizedir. Genellikle atrofik skar birakarak iyileşir. Kesin patogenezi bilinmemektedir. İlacın kan damarına yanlışlıkla enjeksiyonunun ardından oluşan arteryel spazmı takiben gelişen deri nekrozunun neden olduğu düşünülmektedir. Burada uyluk bölgesine diklofenak enjeksiyonunun ardından oluşan Nicolau sendromlu bir olgu sunulmaktadır.

Anahtar Kelimeler: Diklofenak; enjeksiyonlar, intramüsküler

Turkiye Klinikleri J Med Sci 2012;32(5):1437-9

$\mathrm{N}$ -icolau Syndrome (NS) or Emboly Cutis Medicamentosis is a rare complication of intramuscular injection (im) of various drugs. It occurs as local, aseptic and cutaneous, subcutaneous or sometimes muscular necrosis at the area of injection. ${ }^{1}$ Here we presented a case of NS after diclofenac injection, which developed at a localization previously not reported in adults.

\section{CASE REPORT}

A 33-year-old female patient presented to our dermatology department with a painful indurated $3 \times 1 \mathrm{~cm}$ plaque on her right thigh with a necrotic crust at the center and a purplish tissue around (Figure 1). The patient was healthy until 20 days before the development of the lesion. Additionally, she indicated that the lesion had developed after intramuscular injection of 


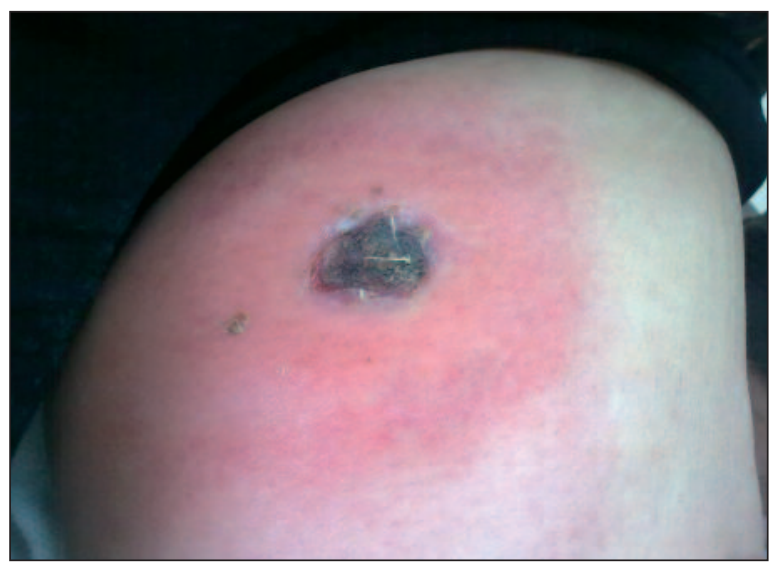

FIGURE 1: Indurated plaque on the thigh with a necrotic crust at the center and purplish erythema surrounding it.

(See for colored form http://tipbilimleri.turkiyeklinikleri.com/)

diclofenac on her right front thigh for headache. She was diagnosed with Nicolau Syndrome according to the medical history and typical dermatological signs. Lesion biopsy was not conducted in order to prevent further damage. Conservative treatment was preferred. Consequently, the lesion regressed leaving a small scar behind.

\section{DISCUSSION}

NS was first defined in 1920 by Freudenthal and Nicolau after using bismuth salt for treatment of syphilis. ${ }^{2}$ Up to date, NS cases have been reported in relation with using antiinflammatory drugs, local anesthetics, corticosteroids, antihistamines, vitamin B complexes, sulfonamides, penicillin, recombinant interferon alpha and beta, vaccines (varicella and diphtheria-tetanus-pertussis), pyrazolone, and etanercept. ${ }^{3-10}$

A possible cause is the development of arterial spasm following a tissue necrosis after the drug is injected into a blood vessel by mistake. ${ }^{1}$ Actually, diclofenac is a cyclo-oxygenase inhibitor and inhibits synthesis of prostaglandin. This may lead to the vaso-constructive phenomenon. ${ }^{10}$

Typically, severe pain develops right after the intramuscular injection. Vasospasm leads to paleness, which is followed by an erythematous macule. Subsequently, within 24 hours, a livedoid patch occurs which may develop into a hemorrhagic or necrotic stage. Within the next 1-2 weeks, necrosis or demarcation develops including the muscle. Finally, it heals by leaving an atrophic scar behind. ${ }^{11}$ NS may be accompanied with widespread cutaneous necrosis, ipsilateral limb ischemia, and various neurological complications and superimposed infections. ${ }^{3}$

For intramuscular injections, generally thighs are preferred in children and gluteal area in adults. In reported cases up to date, lesions have been compatible with these preferences. However, in our case, the lesion was in the thigh area although the patient was an adult.

There is no definitive treatment of this syndrome. Conservative approach is recommended such as covering the wound, debridement, bed rest, and pain control. ${ }^{12}$

Although the syndrome develops very rarely, it is an important cause for morbidity. It is an iatrogenic condition, especially practiced by nurses. ${ }^{13}$ Thus, although it appears to be a very simple procedure for a healthcare worker, care must be taken during intramuscular injections. Aspiration must be practiced before the injection to ensure that the injection point is correct.

\section{REFERENCES}

1. Mutalik S, Belgaumkar V. Nicolau syndrome: a report of 2 cases. J Drugs Dermatol 2006;5(4):377-8.

2. Faucher $L$, Marcoux D. What syndrome is this? Nicolau syndrome. Pediatr Dermatol 1995;12(2):187-90.

3. Corazza M, Capozzi O, Virgilit A. Five cases of livedo-like dermatitis (Nicolau's syndrome) due to bismuth salts and various other nonsteroidal anti-inflammatory drugs. J Eur Acad Dermatol Venereol 2001;15(6):585-8.

4. Nagore E, Torrelo A, González-Mediero I, Zambrano A. Livedoid skin necrosis (Nicolau syndrome) due to triple vaccine (DTP) injection. Br J Dermatol 1997;137(6):10301.
5. Luton K, Garcia C, Poletti E, Koester G. Nicolau Syndrome: three cases and review. Int J Dermatol 2006;45(11):13268.

6. Guarneri C, Polimeni G. Nicolau syndrome following etanercept administration. Am J Clin Dermatol 2010;11(Suppl 1):512. 
7. Anıl M, Çakmak B, Bal A, Aksu N. [Nicolau syndrome in two children following penicillin injection: case report]. Turkiye Klinikleri J Pediatr 2010;19(2):144-7.

8. Hamilton B, Fowler P, Galloway H, Popovic N. Nicolau syndrome in an athlete following intramuscular diclofenac injection. Acta Orthop Belg 2008;74(6):860-4.
9. Sarifakioglu E. Nicolau syndrome after diclofenac injection. J Eur Acad Dermatol Venereol 2007;21(2):266-7.

10. Ezzedine K, Vadoud-Seyedi J, Heenen M. Nicolau syndrome following diclofenac administration. Br J Dermatol 2004;150(2):3857.

11. Stiehl P, Weissbach G, Schroter K. [The nico- lau syndrome]. Schweiz Med Wochenshr 1971;99(11):266-9.

12. Odom RB, James WD, Berger TG. Andrew's Diseases of the Skin. $9^{\text {th }}$ ed. Philadelphia: WB Sauders; 2000. p.130.

13. Uzun Ş, Arslan F. [Medication errors: scientific letter]. Turkiye Klinikleri J Med Sci 2008;28(2):217-22. 
Copyright of Turkiye Klinikleri Journal of Medical Sciences is the property of Ortadogh Reklam Tanitim ve Yayincilik Turizm Egitim Insaat Sanayi ve Ticaret A.S. and its content may not be copied or emailed to multiple sites or posted to a listserv without the copyright holder's express written permission. However, users may print, download, or email articles for individual use. 